\title{
In pursuit of the rarest of birds: an interview with Gilbert Faccarello
}

GILBERT JEAN FACCARello (Paris, 1950) is professor of economics at Université Panthéon-Assas, Paris, and a member of the Triangle research centre (École Normale Supérieure de Lyon and CNRS). He is presently chair of the ESHET Council (European Society for the History of Economic Thought).

He completed his doctoral research in economics at Université de Paris X Nanterre. He has previously taught at the Université de ParisDauphine, Université du Maine and École Normale Supérieure de Fontenay/Saint-Cloud (now École Normale Supérieure de Lyon). He is a co-founder of The European Journal of the History of Economic Thought, which he co-edited for 20 years with J. L. Cardoso, Heinz D. Kurz, and A. Murphy. With Alain Béraud, he edited the Nouvelle histoire de la pensée économique (La Découverte, 3 volumes, 1992-2000) and, together with Heinz D. Kurz, he is presently editing a Handbook of the History of Economic Analysis (3 volumes, forthcoming with Edward Elgar).

EJPE interviewed Gilbert Faccarello about his research career in the history of economic thought, where he has focused especially on old and new classical and Marxian political economy, and French political economy during the 18th and 19th centuries. G. Faccarello discusses his interest not only in the logical structure and context of the economic ideas of past thinkers but also the links between economic thought, philosophy, and religion.

EJPE: Professor Faccarello, you did your PhD in economics but you have specialized in the history of economic thought. How is it that you first became interested in historical questions? Were there any scholars who particularly influenced your intellectual development?

GILBERT FACCARELLO: I did my $\mathrm{PhD}$ in economics but this heading in France includes the many sub-disciplines of economics, including the history of economic thought. It is true that my master's degree was in international economics, but my doctoral thesis, defended in 1979 and published in a revised form in 1983, was on 'Labour, value and prices: a critique of the theory of value'.

EJPE'S NoTE: This interview was conducted in early 2014 by Joost Hengstmengel and Thomas Wells, editors of this journal. 
You must realize that, when I was studying economics it was still the time of the capital controversy between the two Cambridges, i.e., the time of a fierce critique of the neoclassical aggregate production function and the related theory of distribution. This critique was principally associated with a strong neo-Ricardian revival after the publication of Sraffa's Production of commodities by means of commodities in 1960. As a consequence questions were also raised about the status of Keynes's writings and Keynesian theory, not only vis-à-vis the marginalist approach but also in relation to Sraffa's work and neo-Ricardian developments. Finally, all this rekindled the debates around Marx's theory, especially about the theory of labour value and the problem of the transformation of labour values into prices of production-and of course, in this case also, about the Marxian theory of distribution and the alleged law of the falling rate of profit.

Thus, at that time, economic theory, history of economic thought, and methodology were intimately intertwined. Consider that this was also the period when Paul Samuelson started to publish papers in HET. My doctoral thesis reflected this general mood. It dealt with the different attempts which had been made by many authors-from Smith to Sraffa and the neo-Ricardians, via Ricardo, Marx, Dmitriev, Bortkiewicz, etc.-to establish links between the concepts of labour, value and prices, attempts which were almost always coupled with the defence of specific theories of income distribution. I tried to understand why none of the links which were proposed could withstand critique. In my opinion this meant that this question of the links was not correctly posed, probably because the basic concepts had not been defined properly. These concepts, in particular the concept of labour-e.g., 'abstract labour' and 'socially necessary labour' in Marxhad thus to be reconsidered and redefined. All these points naturally entailed methodological and philosophical issues. For example, in the case of Marx this led me to reconsider his supposed links with Hegel, to examine precisely what Marx had borrowed from the Wissenschaft der Logik and Grundlinien der Philosophie des Rechts and why it was necessary for him to do so. I thus tried to disentangle three different strands in Marx's discourse, what may be termed the technological, sociological, and dialectical. Marx no doubt thought that these lines of thought were complementary and necessary for his intellectual project. But I reached the conclusion that they were actually in conflict with each 
other because, among other things, they entailed different and conflicting concepts of 'abstract labour'.

During all these formative years, I benefited of course from extensive reading, especially in English, Italian, and also German-the literature in the French language was very poor, to say the least, and not only in HET but throughout economics in general. Reading Sraffa and some papers from the Cambridge controversy in the seminar run by my supervisor Gilbert Abraham-Frois-who subsequently published a book with Edmond Berrebi, Theory of value, prices and accumulation-was exciting. Geoffrey Harcourt's book, Some Cambridge controversies in the theory of capital, which had just been published, was also important for us, together with those of Maurice Dobb, Ronald Meek, and John Hicks.

On the Marxian side, I was very dissatisfied with the traditional Marxist literature. I found the way in which Marx was read and commented upon totally uncritical and uninteresting. I was looking for new approaches. A short paper by Hans-Georg Backhaus on the 'Dialektik der Wertform' (1967), and a book by Helmut Reichelt, Zur logischen Struktur des Kapitalbegriffs bei Karl Marx (1970) were of great interest together with some works by Isaak Illych Rubin, especially his Essays on Marx's theory of value, an incomplete German translation of which I bought in Berlin in 1974; I subsequently bought the German 1975 translation of a debate between Rubin and S. A. Bessonow, Dialektik der Kategorien. Once back in Paris, I suggested a complete French translation of the Essays to colleagues in charge of the journal Critiques de l'économie politique, published by the left wing publishing house of François Maspero. It came out in 1978, translated by JeanJacques Bonhomme, after the English translation by Milos Amardzija and Fredy Perlman published by Black and Red, Detroit, 1972. Subsequently Rubin's History of economic thought was published in English with Ink Links in 1979. I am glad that there is now a kind of Rubin revival, in Russia, Germany, and Japan where publications of some of Rubin's manuscripts came out recently. As usual, France is unfortunately lagging behind.

On the Italian side the debates were lively and generated an impressive number of papers and books. I benefited a lot from the writings by Claudio Napoleoni, for example, and I also remember the publication of an Italian translation of a series of essays by Ladislaus von Bortkiewicz, edited by Luca Meldolesi (Einaudi 1971). But the greatest influence probably came from Lucio Colletti, an Italian 
philosopher whose book Il marxismo e Hegel (1969) impressed me a lot; his long introduction to Marx's Early Writings (1975) was also of great interest. In particular, he showed clearly why Engels's line of thought was not only irrelevant but also a highly misleading guide to the interpretation of Marx's writings; and how Marx's own position was much deeper and more complex than was usually claimed. But Colletti, like Rubin, did not go so far as to radically criticize Marx's discourseand that is precisely what I tried to do, re-evaluating Ludwig Feuerbach's approach at the same time. Feuerbach was not only essential to Marx's youthful critique of Hegel's philosophy; Marx also accepted Feuerbach's definition of abstraction and made decisive use of it in his characterization of the concept of money and in one of his most interesting definitions of abstract labour.

\section{You teach a seminar class on 'Methods in the history of economic thought'. What is your perspective on the methodology of HET?}

On this point I am a kind of anarchist. I do not think that there is only one way to do good research in HET. It is true that I have always rejected the retrospective 'Whig' approach as sterile and irrelevant. I have always been in favour of historical methods, with the condition of course that the links between economic theories and their historical 'contexts', their intellectual environments-philosophical, religious, political-be taken seriously and not treated as merely a kind of decorative but inessential wallpaper. But this delimits a very broad field. Specific historical methods and approaches are numerous-including the good old history of theories-and you are free to choose which one suits you best. It all depends on what you would like to study. Just show me your results: only the novelty and the quality of the results are important, not the road you take to reach them.

In this respect I think that simple oppositions between internalist/ absolutist and externalist/relativist approaches, or between rational and historical reconstructions-do you know of any 'irrational reconstructions'?-are rather superficial. If we would like to reflect on our own practices as historians of economic thought-and I do not deny that this is useful and even necessary-we must face up to much more complicated and complex problems. We are unavoidably embedded in a particular historical horizon, as are the authors and works we are analyzing. One of the first things to do then is to try to determine what are the precise meanings of concepts like 'explain', 'understand', and 
'interpret'-and also what is a 'text' or a 'work'. To put it briefly, economists and especially historians of economic thought should take into account the history and developments of hermeneutics since at least Friedrich Schleiermacher and Wilhelm Dilthey, and particularly the writings of Hans-Georg Gadamer and Paul Ricœur-not to speak of the numerous debates they raised, for example with Jürgen Habermas. In my opinion this is a fundamental task.

On the other hand, insisting too much on 'method' presents two dangers. The first is to think that adopting a particular 'correct' method is an infallible path to wonderful results. This is doubly misleading because, first of all, committing to one method does not ipso facto provide any guarantee of success. Good research also depends on chance, coincidence, accidents, and above all on one essential element which cannot be taught: scientific imagination. Second, sticking to a single method can be paralyzing, especially for young scholars. In this respect we should bear in mind Montesquieu's warning: "vous ne pouvez plus être occupé à bien dire, quand vous êtes sans cesse effrayé par la crainte de dire mal". ${ }^{1}$ Nietzsche said the same thing in substance: don't ask yourself what is the best way to climb the mountain, just climb! $!^{2}$

The second danger is dogmatism and intolerance. Those who are imprisoned by strict rules are sometimes led to despise any other approach and to become involved in sterile polemics on the subject. Unfortunately we are sometimes confronted in HET with the same sectarian attitudes we find in other fields of economics, where colleagues almost religiously follow one line of thought and excommunicate all who do not. This reminds me of Armande's speech in Molière's Femmes savantes: "Nul n'aura de l'esprit, hors nous et nos amis"! !

When I studied the theories of Boisguilbert and Marx I felt the necessity to combine an analytical approach with historical and philosophical point of views. This was the only way, in my opinion, to reconstruct the coherence of these authors, to make the full complexity

\footnotetext{
1 "You can no longer be engaged in speaking or writing well, when you are constantly afraid of impropriety"-Defence of the spirit of the laws, part III (free translation).

2 "Wie komm' ich am besten den Berg hinan? Steig nur hinauf und denk nicht dran!"Die fröliche Wissenschaft.

${ }^{3}$ Molière, Les femmes savantes (The learned ladies) - Act 3, scene 2. Armande: "We, by our laws, shall judge of all new works; / We'll rule both prose and verse, whatever's writ; / Except our friends and us, none shall have wit; / We'll spy out faults in everything and find / None but ourselves to write in style refined".
} 
of their theories and beliefs intelligible. When I studied the historical reception and dissemination in France of the writings and ideas of Adam Smith (with Philippe Steiner) or David Ricardo (with Alain Béraud), we adopted a more historical approach but without giving up the analytical point of view. The analytical approach is in turn predominant in my work on the history of public economics in France, and in my study of Ricardo's theory of international trade.

\section{What about your seminar on 'Methods in the history of economic thought'?}

My 'séminaire de méthode' does not really deal with 'methods' in the history of economic thought. Maybe the name is ambiguous. It is more modest in its aims: a seminar where students can learn how to read texts in a critical way.

To learn how to critically read a text is in no way superfluous, at least in France. During their prior studies, most students are accustomed to just working to pass exams, and to pass exams you are supposed to know what you have learned. In this seminar I try to make them realize that the attitude of a researcher is precisely the opposite: research starts when you recognize 'I do not understand'. They do not have to be afraid of speaking in this way, even when they read texts by prestigious authors.

We read and comment on works from different periods, for example the controversy between Bodin and Malestroict on the links between money of account, species, and prices-in the original version; Bernoulli's 1738 paper on his new theory of the measurement of risk, sometimes confronting different translations; or Keynes's 1911 review of Fisher's Purchasing power of money together with the first section, on the quantity theory of money, of chapter 3 of his Tract on monetary reform, etc. The analysis of these texts is driven by very simple questions: Against whom is the author writing? Which thesis is put forth? What is the structure of the argumentation? Is it convincing, and why? We pay attention to the vocabulary employed and its special meaning in a specific theoretical, historical or philosophical context-even if the meaning of words seems obvious at first sight. All this shows the students how careful a reading ought to be. On specific subjects-Boisguilbert or Smith for example-I or an invited speaker go deeper into the links between philosophy and the development of economic thought. We also spend some time examining the material 
aspects of the documents-hence our use of the original 16th century version of the Malestroict/Bodin texts.

In order to widen their horizons, I also recently began inviting young scholars who are writing a $\mathrm{PhD}$ thesis to attend some specialized conferences in HET, even if the topic is far from their own research. For example, at the conference on 'New developments on Ricardo and the Ricardian traditions' that we organized last September in Lyon together with the Ricardo Society Japan, the day before the conference opening was devoted to a series of lectures on various aspects of Ricardo's thinking to prepare the invited students for the conference sessions. The results were very positive and I plan to repeat the exercise. I think this kind of thing is an excellent complement to the annual European Summer School in the History of Economic Thought.

There is one point however over which I still quarrel with students. Although I distribute the texts in the form of PDFs, I urge students not to read them on the screen of their computer or tablet but to print them out and use a simple pencil to annotate them assiduously with their remarks, questions, and the like, as they read and re-read them. But I am afraid my arguments in this regard do not seem to be totally convincing! I know that annotation functions in electronic readers are improving, but they still lack the necessary flexibility to be really useful.

What do you think is the aim of the history of economic thought as an academic discipline? Does it contribute to the understanding of contemporary economics by researchers and students?

The history of economic thought is first of all a sub-discipline of its own, à part entière, like labour or monetary economics. We do not have to apologize for being researchers in HET, nor feel guilty for the aesthetic pleasure we feel when reading 'ancient' texts. It is true that this does not contribute directly to solving contemporary problems, though it can suggest ideas for further theoretical elaboration. But it certainly helps us to understand those problems in a deeper way, and contemporary economic theory and concepts in general.

Moreover a solid training in HET provides an antidote to the narrow purely technical and mathematical training that most students now receive in schools and universities. I am not at all against formalization and the use of technical tools. But training in economics cannot be confined to this kind of technical approach without generating a loss of contact with reality and the pressing problems of today. When I look 
at the content of many of the professional journals in the faculty library, I feel that we are back in the heyday of Scholasticism when Schoolmen were bitterly debating how many angels could dance on the head of a pin... Of course, those Schoolmen were convinced that this was an essential activity for the advancement of knowledge and the common good; just as some economic 'theoreticians' today!

A training in HET is all the more necessary because students (and teachers) are also usually highly specialized by topic and thus unable to reason on subjects outside of their precisely defined field of competence. HET can open new horizons, and that can help one to think in a more comprehensive and critical way. In this perspectiveparaphrasing Keynes-the study of HET is a necessary preliminary to the emancipation of the economist's mind. It allows one to see the analogies but also the differences with past events and controversies. And this is not superfluous. It is astonishing to see old ideas being put forth again and again in various guises, in public debates as well as in research papers. To take just two academic examples, economists would have had a better idea of the supposed novelty of the ideas Milton Friedman developed in his celebrated 1968 paper on 'The role of monetary policy' had they read Dennis Robertson; and the phenomena of adverse selection 'discovered' a few decades ago would have seemed rather less radical if some striking passages on banking activity and the fixation of interest rate limits in the Wealth of nations had been seriously studied.

It is significant that after every crisis the public, the press and even economists suddenly show some interest in economic history and HET. This was the case recently following the subprime crisis, when the social and professional status of economists and financiers was seriously shaken. They were accused of having developed useless-or even dangerous-models and practices, and of being quite wrong in their forecasts. Even Queen Elisabeth II noticed this, and she asked the right question on the occasion of her 2008 visit to the London School of Economics: why did no one see it coming?

But unfortunately this interest in HET did not last, except perhaps for a renewed attention to the writings of Keynes without any practical consequence, at least for the time being. Most people tend to be forgetful again once a crisis seems over and they are happy to go back to their old daily routines. When I was a student, we discussed the respective merits of Kuhn, Lakatos, and Feyerabend regarding the 
sociology and methodology of science and the structure of scientific revolutions. I confess that I preferred the way Lakatos dealt with these questions. I realize now that Kuhn was also right, and that I underestimated the strength of the practice of 'normal science'. "In the long run, the economic scholar works for the only coin worth havingour own [the profession's] applause", Samuelson once wrote $(1962,18)$. Alas, this is very true. It is the dark side of the 'scientific community'.

It is of course possible to come up with many other excellent reasons to study and to teach HET-see for example Mark Blaug's 2001 repentance, or Heinz D. Kurz's 2006 ESHET presidential address. But its role in a better understanding of economic concepts and the development of a more comprehensive and critical way of thinking seems to me essential.

One hundred and fifty years ago John Stuart Mill stressed the necessity of overcoming narrowness in thinking. "If a political economist is deficient in general knowledge", he stated in Auguste Comte and positivism, "he will exaggerate the importance and universality of the limited class of truths which he knows". A "liberal mental cultivation" is a necessary if not a sufficient remedy "against this narrowness [for] a person is not likely to be a good political economist who is nothing else" (Mill 1865, 306).

A few decades later, in his 1924 essay commemorating Marshall, Keynes wrote a few sentences along the same lines that are worth meditating. Max Planck once told Keynes that he had been interested in economics but he had felt that it was too difficult for him. "Professor Planck could easily master the whole corpus of mathematical economics in a few days", Keynes commented. "He did not mean that! But the amalgam of logic and intuition and the wide knowledge of facts [...] which is required for economic interpretation in its highest form is, quite truly, overwhelmingly difficult" (Keynes 1924, 186n). The way in which Keynes detailed the difficulties is worth quoting. Economics, he stressed, is not a priori a difficult subject-"compared with the higher branches of philosophy and pure science". This notwithstanding, "good, or even competent economists are the rarest of birds. An easy subject, at which very few excel!" Why is it so?

The paradox finds its explanation, perhaps, in that the mastereconomist must possess a rare combination of gifts. He must reach a high standard in several different directions and must combine talents not often found together. He must be mathematician, 
historian, statesman, philosopher-in some degree. He must understand symbols and speak in words. He must contemplate the particular in terms of the general, and touch abstract and concrete in the same flight of thought. He must study the present in the light of the past for the purposes of the future (Keynes 1924, 173).

No doubt some will say this is an old-fashioned view, or too unattainable a model-or even that Keynes is only describing himself. But I presume all will agree that this kind of economist is still today the rarest of birds and that the present ways of teaching economics will not, to say the least, make them any more common.

\section{Turning to your own research, you often write about early-modern, pre-Smithian economic thought. What is it that particularly interests you about this period?}

Please allow me a remark on your terminology, which is extensively used in our discipline. I think that categories like 'pre-Smithian economic thought' are misleading. Why not 'pre-Turgotian', 'pre-Ricardian' or 'pre-Keynesian' economic thought? In the case of 'pre-Smithian economics', it is taken for granted that Smith was the founder of political economy and that contemporary economists are "the sons and daughters of Adam Smith" (Samuelson 1962, 1). There would be a before (non-scientific) and an after (scientific) Smith; a point of view that is totally biased and which moreover gives a false image of Smith, as the wealth of research published on his work in the last three decades demonstrates. I know that the label 'pre-Smithian economics' is still widely used by historians of economic thought, but this is unfortunate and suggests an intellectual inertia, or at least that the results of research take a long time to be accepted and integrated into our professional language.

I was (and I am still) particularly interested in the works of 17 th and 18th century authors because, first of all, there is much to study in this field. The case was probably a bit different for English or Scottish authors, but, when I started to study HET, I realized that as regards Continental Europe the publications of that period were either neglected or dealt with in terms of the retrospective approach. At best their authors were considered as 'precursors', i.e., unimportant, just curiosities, the only elements of interest in what they wrote being precisely those which vaguely foreshadow some theory stated much later. This is an incredibly sterile approach which in the end cannot 
uncover anything new. HET is not the history of a cumulative scientific truth which has been reached by discarding errors. It is certainly not the study of 'the wrong opinions of dead men'.

My aim was instead to take these authors seriously and to reconstruct their thinking as completely as it is possible to do in our own historical horizon, paying much attention to their historical and philosophical environment. What was needed was to reconstruct the logic and coherence of their arguments. A typical example is the work of Pierre Le Pesant de Boisguilbert who was only considered as a precursor of Quesnay; or even Turgot-an extraordinary theoretical mind, who is himself still all too frequently mentioned only as a 'dissenting Physiocrat', which does not mean anything. Not to speak of Jean-JosephLouis Graslin, Alexandre Vandermonde or even Ferdinando Galiani. This did not exclude research on more specific points. I tried for example to show how the debates between Turgot, Galiani, and Necker were politically and theoretically significant because they discussed, with valuable arguments on both sides, the difficult problem of how to design a successful economic policy in the context of the transition from a regulated to a free market economy. That was a very rich debate. Ironically enough, approximately the same questions were topical again quite recently, after the collapse in Eastern Europe of the political and economic regimes of the USSR and the so-called 'People's democracies'. I tried also to show how Vandermonde, while not a first rank theoretician, had nevertheless been important during the French Revolution, paving the way to Say's and Destutt de Tracy's concept of productivity.

Another powerful reason to study seriously these 17 th and 18th century (but also more ancient) authors lies in the complex relationships they maintained with, broadly speaking, philosophical ideas. Most of the time these ideas are of no minor interest for these authors and powerfully motivate the questions they raised and the solutions they tried to find. The case of Boisguilbert is striking. His attitude towards the Jansenist currents of thought, together with the friendly attitude Jansenists had towards Cartesian physics, allow us to reconstruct in a better way his approach and results. Another striking example is Graslin. His Essai analytique sur la richesse et sur l'impôt (1767)—and his Dissertation of Saint-Petersburg (1768), for the few commentators who were aware of it-always raised a serious problem of interpretation. His writings have generally been considered to be important, but 
commentators have never agreed on the reasons for that-and this is what happened in the case of Boisguilbert's writings, too. Whence a very vague image of Graslin as a 'forerunner' of just about everybody-again, like Boisguilbert. In order to find out what he was really about, I tried to combine intellectual history and an analytical approach. This allowed me to see how Graslin based his approach on ideas borrowed from Jean-Jacques Rousseau-especially from his Discours sur l'origine et les fondements de l'inégalité parmi les hommes (1755)-and sensationist philosophers like Maupertuis or Charles Bonnet. It was then fascinating for me to uncover how Graslin tried to develop a kind of Rousseauist political economy and how his construction can also be considered as the foundation of classical political economy-in the sense that it entails a theory of the natural prices of commodities based on the 'conditions of production' and a theory of market prices as 'gravitating' around these natural prices, a special case being a labour theory of value. It was also interesting to see how and why, like some of his contemporariesCondorcet for instance-Graslin paid great attention to certain questions of public economics like market failures and the free rider problem, or how he distinguished complementary from substitutive goods.

For those who are interested in the multiple links between economic theory and philosophy, this period is central. This is not to say, of course, that these links disappeared afterwards and that economics finally became an autonomous science mimicking the model of physics. The old thesis of a progressive independence of economic theory vis-à-vis philosophy, politics and religion-which Louis Dumont tried to revive in the 1970s in his Homo oequalis - cannot be accepted. To believe that economic theory became a science through cutting away at any kind of link with philosophy, politics and religion-'freeing' itself from them and the intellectual environment out of which it progressively emerged-remains a kind of fundamental illusion. While more discreet, those links are still there, and of material importance. With Philippe Steiner I have tried to show how political economy presented itself as a new political philosophy. Succeeding centuries of domination by religion on behaviours and thoughts, it imposed a new ethos, a new 'conduct of life' to use Max Weber's phrase. This is what we called 'philosophie économique'. 


\section{Could you explain what this phrase 'philosophie économique' means and why it is so interesting to you?}

As you know, in the specific intellectual context of 18th century France, almost every intellectual was said to be a 'philosophe', i.e., a person who thought freely and against prejudices and worked for the advancement of science and truth. Quesnay and the Physiocrats were known as the 'économistes' or 'philosophes économistes'. They were seen by many as philosophers who had not only developed a new science but also subverted the traditional wisdom for the counselling of the government of a state because they put the 'science de l'économie politique' or 'science économique' at the centre of the legislator's concerns. In fact they proposed a new political philosophy based on a new ethics.

This attitude was labelled 'philosophie économique' by some contemporary authors. The phrase was first coined in 1767 by Nicolas Baudeau, the founder of the Éphémérides du citoyen - which became the organ of Physiocracy-and who is also noted for having called Quesnay the 'European Confucius'. It appeared first in the Éphémérides and then in a book probably written at the same period but only published in 1771, Première introduction à la philosophie économique ou analyse des États policés. It was also picked up by Gabriel Bonnot de Mably, who was critical of this kind of discourse. The attitude of Quesnay and the Physiocrats was not new. It started with Boisguilbert some decades before, was also Turgot's, and was continued by Paul Thiry d'Holbach, Claude-Adrien Helvetius, and Jean-Baptiste Say. This new approach to politics, ethics, and society-this new political philosophy-was both positive and normative and tried to impose a new 'conduct of life' favouring the development of a market economy and the accumulation of capital. To express this we tried to build an ideal-type along Weberian lines. It is this ideal-type we chose to call 'philosophie économique' because we thought this was the best contemporary expression. In constructing it we focused on three elements: a self-interested conception of human behaviour; a theory of knowledge essentially based on sensationism; and a peculiar attitude to the Legislator which evolved through time. We have developed our idea in two co-authored papers.

Weber himself wrote that the relevance of the ideal-type he developed in his studies on Die protestantische Ethik und der Geist des Kapitalismus stopped at around the end of the 17th century. It seemed to us that, in France, from that date to the period of the 
Restoration-i.e., the beginning of the 19th century-our new ideal-type was useful in understanding the fundamental changes in the political, ethical and philosophical ideas that characterised the period.

Your best-known and most-cited book deals with the economic writings of Pierre de Boisguilbert, whom you have already mentioned several times. Marx called him one of the founders of classical political economy, together with William Petty. How important was Boisguilbert's work to the development of modern economics?

Marx was certainly a poor historian of economic thought, simply because he was not interested in HET per se. His approach is totally retrospective. He almost always judged the authors who wrote before him by a sole criterion: did they foreshadow or anticipate his own theory? Were they his 'predecessors' or not, and on which points? Classical political economy, according to him, included the works of all those who tried to understand the real production relationships in a capitalist society, i.e., to describe what happens behind the curtain of the market, unveiling what is hidden. And 'vulgar economists'-those who were satisfied dealing with mere appearances-were in his view the apologists of the system. Stated as such, this is a rather vague criterion. Something had to be added. The touchstone was in fact the labour theory of value. As he put it in Zur Kritik der Politischen Ökonomie (1859), Petty in England and Boisguilbert in France initiated the scientific movement on this point which led to Ricardo and himself. This is of course an inaccurate statement: I cannot see any reference to or 'anticipation' of a labour theory of value in Boisguilbert. On the contrary he developed an account based on the interaction of demand and supply in markets and, on this basis, determined a system of relative equilibrium prices he called 'prix de proportion'.

In Theorien über der Mehrwert (1862-1863)-where, if I am not mistaken, Boisguilbert is referred to only once-Marx maintained that Boisguilbert was a forerunner of the Physiocrats who, in his view, showed that the "surplus value" was created in the sphere of production-even if this sphere was limited to agriculture-and not in the sphere of circulation. But there is nothing similar in Boisguilbert.

In fact what Marx found of greatest interest in Boisguilbert were his thoughts on money. The greatest number of references to Boisguilbert is to be found in Grundrisse (1857-1858), Zur Kritik (1859) and the 1858 primitive version of it, and they concern precisely this theme. Marx is 
attracted by the many passages where Boisguilbert violently stressed the damaging effects of the passion for money, gold, and hoards, and insisted that money, which should only have been the servant of trade in its functions of measure of value and medium of exchange, became its tyrant in its role of a store of value and as a consequence contributed to generating crises. It is on this aspect that Marx contrasted English and French (classical) political economy-Petty and Boisguilbert-an opposition that, he wrote, was a lasting one because it was still to be found between Ricardo and Sismondi. Contrary to Boisguilbert who was supposed to fight money, stressing repeatedly that genuine wealth consisted in the amount of commodities produced and not species, Petty was said to praise gold and the love of money because of their beneficial consequences for economic growth and the extension of markets.

Notwithstanding Marx's flawed interpretation, Boisguilbert was important in the development of political economy. On the basis of his religious belief and his stress on the Fall and Original Sin, he put the depraved, selfish, maximizing behaviour of agents at the centre of his analysis of the functioning of interdependent markets. From this conception of agents, together with their information and expectations, he determined the conditions of an optimal equilibrium of the economy, the 'état d'opulence', and proposed a laissez-faire policy-'liberté du commerce'-and a limited role for the State (justice, police and defence). This equilibrium-he used the term-is characterized by a system of relative prices, the 'prix de proportion' already alluded to. Absolute prices and the quantity of money in circulation do not play any decisive role in his analysis. Money as a circulating medium is for the most part endogenous: Boisguilbert thought his contemporaries were wrong to believe that the quantity of specie was too low and a cause of crisis. The fact that money does not circulate is not the cause of but a consequence of a crisis, the real causes of which are to be found elsewhere-essentially in bad economic and fiscal policy and the regulation of markets. Boisguilbert also analyzed possible destabilizing shocks and how a crisis could develop in one sector of the economy, especially agriculture, and then spread to the other sectors and become general. He also developed a circular flow approach in order to take into account the economic role of rentiers and the State.

These themes formed the legacy that Quesnay and the Physiocrats on the one hand, and Turgot and sensationist political economy 
on the other, took up in two rather complementary ways. In my opinion, however, Turgot, by substituting sensationist philosophy for Boisguilbert's theological point of departure in explaining the behaviour of agents, was the one who developed this intellectual legacy the most rigorously and farthest.

Coming back to Marx: he did not properly understand some French 17 th century vocabulary-for example 'finance' and 'financiers'-and this explains some of his judgments. Moreover he worked on a faulty edition of Boisguilbert (the Daire edition, published in the celebrated Collection des principaux économistes in 1842). We had to wait for the beautiful 1966 INED edition of the works and correspondence of Boisguilbert by Jacqueline Hecht, including a substantial number of previously unpublished manuscripts, to get a better understanding of this architectonic author.

Except for your work on the 19th century, most of your publications deal with French economists or economists who wrote in France/French. Do you think that, in describing the rise and development of modern economics, there exists a bias towards the British contribution? If so, why is the French contribution underestimated?

There is certainly-or rather there was, because it seems that things are now changing again-a bias in favour of English-writing authors. This bias came strongly to the fore after World War II. If you look back to the 19th century or the beginning of the 20th, scholars paid more attention than today to what happened in different countries. As Samuelson remembered (1962, 3): "When I began graduate study at Harvard in 1935, Schumpeter rather shocked me by saying in a lecture that of the four greatest economists in the world, three were French". Well, it is true that Schumpeter came from Austria, but his case is not isolated. Things changed in a decisive way with the acceleration of the professionalization of economists after 1945-which gave the USA a political and intellectual dominance over economics, as in other fields. It was moreover easier for native English-speaking economists-rather reluctant to learn other languages or to consider research not written in English-to concentrate on their own heritage. This set the tone and in other countries many other scholars tended to imitate them and publish on the same themes. The great controversies, like the debates on capital theory already alluded to, on Keynes, on Ricardo, and so forth, also 
played an important part in this focusing on Anglophone authors and writings. Historians of economic thought are not locked up in ivory towers-we also follow fashions and topicality.

Fortunately there were some exceptions. 'Big names' like Quesnay, Turgot, Say, Cournot, Dupuit, Walras, Marx, or Pareto always attracted some attention. But they remained exceptions. Note that what I just said of economists is certainly not true of English-speaking historians who never lost a wider perspective.

To this must be added the fact that, during the last two centuries, a great number of first-rank theoreticians, from Ricardo to Keynes, were British or American. And as historians of economic thought used to understand their discipline as the history of theories, this could explain the concentration of research on works published in English and the relative neglect of writings and debates in other languages. This is not to say that the latter were not studied. But the problem of language was a serious impediment to the reception and spread of research findings.

Two complementary problems which today do not exist any more also formed no mean obstacle to wider research. The first were the scant possibilities to publish a paper in HET in an Anglo-Saxon journal without dealing with subjects which were supposed to be of interest to this journal and its narrow range of referees. Now of course the spaces for publication are rather numerous, the profession is well organized and, thanks to the internet, communication with authors and referees from all over the world is incredibly easy. All these transformations over the last two or three decades are of material importance and no doubt favour the multiplication of subjects, themes and methods in HET.

The second reason was the simple (un)availability of the texts-the more ancient they were, the more difficult they were to find-and, more generally, of meta-information about the texts such as would allow tracing related works published during a given period. Today, with the internet and especially thanks to sites like Gallica (the electronic library of the Bibliothèque Nationale de France), Google Books, or Archive.org, and many other institutions, researchers can immediately have at their disposal a huge number of texts in various languages and all the metainformation that scholars of my generation could only get after months of detective work in libraries. By simply typing some words on your keyboard you can find very interesting references that you did not at all expect and which widen your horizon. The real challenge now is not to get documents and information, but how to manage and make good use 
of them-and the problem is serious for students starting a research project. Of course, this aspect of things depends on the subject: if you are studying Keynes's Treatise on money or the monetary theory of Walras, the problem is different. What I would just like to stress here is that one can now easily have a better view of the wealth of literature and debates in various countries. This is how, a few years ago, I discovered the richness of the debates about public economics among 19th century French economists, or the huge and highly varied French literature on population, poverty, and wealth.

When it comes to 19th and 20th-century economics, you seem to be particularly interested in Ricardo, Marx, and Sraffa. Is there a philosophical connection between these economists?

No, I do not think there is any philosophical connection between them, at least not any deep connection. Ricardo and Marx had different approaches. Sraffa owes something to both of them but he was working in a totally different intellectual context, well described in some recent contributions by Heinz Kurz based on the still unpublished Sraffa papers deposited in Trinity College, Cambridge. The only link I can imagine between the three of them would be a kind of positivist 'scientistic' attitude. But this is rather superficial a link.

In fact, after my book and some papers on the topics you mention, I did not do any more original research on the 19th century for a long time. I was interested in other subjects, and I felt it was not good for me to spend too long digging in the same place. Better to come back later, with a fresher mind. As we already discussed, I turned to the French 17 th and 18th centuries, but also to the 20th. For the past 15 years, I have been teaching a seminar on Keynes-not the Keynes of the General theory and after, but the Keynes before 1936, starting with his first writings-'Keynes before Keynes' is the title.

However, I have returned to the 19th century in the last few years. First to the French 19th century, with papers on the history of public economics during this period, on the debates around poverty, population and wealth, on the various associationist trends of thought and finally on the role of the different religious faiths, old and new, in the controversies of the time. Of course Say, Cournot, Dupuit, and Walras are well known, but unfortunately research into the French 19th century usually only focus on 'big names'. This is a pity because the period is infinitely richer, both analytically and from the point of view 
of intellectual history. Be they liberals or anti-liberals, conservatives or socialists, the variety of opinions is incredible, as is the number of subjects they engaged with.

I am also returning to Ricardo and English classical political economy. It is really interesting to read these texts again after so many years and to re-discover them from another perspective. Sometimes my two 19th centuries connect with each other. For example I just published, with Alain Béraud, a study on the reception of Ricardo's writings in France. It was fascinating for us to see how the two worlds communicated, and how, why, on which points and by whom Ricardo's ideas were accepted, modified, criticized, or rejected over the following six or seven decades, and also how he influenced, directly or indirectly, various developments in economic theory on this side of the Channel.

In your research you often pay attention to theological issues. Recently you launched a research programme entitled 'The conflictridden development of modernity: theology and political economy'. What does theology have to do with economics?

Religion has been very important at decisive moments in the development of political economy. On this topic we usually think spontaneously of classical Greece and Scholasticism. But religion was still significant, though in a more discreet or even hidden way, from the seventeenth century onwards. And this should not be surprising. After centuries of religious domination, you cannot expect people to suddenly change their mentalities and totally erase the ideas which so powerfully shaped their intellectual cultures. Let us take an example. Historians of economic thought often quote Petty's assertion that he wanted to reason in terms of 'number, weight, and measure', and it is taken for granted that it represented the new scientific ethos of the time and a break with Scholasticism. It is true that this phrase is often quoted by 17 th century scientists. But, interestingly enough, it comes from the Bible (Wisdom of Solomon, XI, 20-21).

I was first confronted with religious schemes of thought when studying Marx and trying to find the inner logic of his argument. I do not allude to the well-known 'opium of the people' but to something more fundamental. When discussing and trying to logically analyze the concepts of commodity, value, money and capital, Marx often used religious metaphors which, following Colletti, I proposed to take 
seriously because they are in my view a key to the correct interpretation of many difficult or enigmatic passages in Marx's writings.

I was further confronted with theological disputes when I studied Boisguilbert. I started to read Boisguilbert by chance-I had to teach a course in the history of economic thought and I did not understand what I had read about him in the standard histories of economic thought. Fortunately I had bought the Hecht edition. I started reading and with every page more and more questions came to my mind. One thing led to another. I examined the Jansenist controversies of the time and found that I could interpret Boisguilbert's theories as an answer to some important questions being raised at that time in religious, moral, and political debates. In this case, and quite unexpectedly to me, religious ideas and beliefs were of material significance in shaping the political economy of free trade.

And this is not an isolated case. Philippe Steiner (2011) recently showed how Hermann Heinrich Gossen was inspired in his theoretical research by his religious faith. A decade or two ago, the writings of Maurice Potron-a French mathematician and Jesuit who wrote at the beginning of the last century-were rediscovered and republished. It is amazing to see how his faith and his search for a 'just price' could push him to elaborate a theory of prices of production and to find a mathematical solution for the existence of a system of equilibriumrelative prices-he used the Perron-Frobenius theorem as early as 1911 (Bidard, et al. 2009). It is striking too to see how Potron used, without knowing his writings, almost the same words as Boisguilbert. To define equilibrium prices, Boisguilbert used the condition that "il faut que chaque métier nourrisse son maitre": for Potron, it was the translation of the prayer "give us this day our daily bread".

Religious thinking was also the source of important 19th century critiques levelled at liberal political economy by many authors from very different points of view-protestant, conservative catholic, liberal catholic, and socialist. As a matter of fact many socialist or associationist doctrines in France during the first half of the 19th century were inspired by religious ideas, old or new; doctrines that Marx and Marxists tried to dismiss but which not only played a major role in French culture and history, but were also much more important than avowed for the development of Marx's thought itself. It is also remarkable to note that the religious critique of liberal political economy motivated the foundation of sociology-and later 'economic 
sociology'-by Auguste Comte, Émile Durkheim and the Durkeimians, and so on, as Steiner (2005) clearly showed in a recent book. And coming back to economics, it is fascinating to see that the Protestant and Catholic critiques were rather similar at the beginning of the 19th century but diverged afterwards and by the end of the century were associated with two radically different models of economic and social organization-one founded on liberty and association, the other on authority and new corporations.

All this of course runs counter to, or challenges, the famous 'secularization thesis', which has been around for at least 150 years though its intellectual foundations are continuously shifting. I am not the first, of course, to be interested in this kind of research. But there is a need for more systematic study of the role of religious thought in HET. This is the reason why I proposed the research programme you mention. I also think that an international comparative study is essential in this field because the histories of the links between religion and political economy are not the same in every country. What happened in France, for example, is different from what happened in Great Britain or in the United States, Italy, or Germany. I am quite confident that the new research this programme will foster will bring interesting results and could well change or at least greatly enrich our perception of the history of economic thought.

\section{REFERENCES}

Béraud, Alain, and Gilbert Faccarello. 2014. 'Nous marchons sur un autre terrain'. The reception of Ricardo in the French language: episodes from a complex history. In The reception of David Ricardo in continental Europe and Japan, eds. Gilbert Faccarello, and Masashi Izumo. London: Routledge, 10-75.

Bidard, Christian, Guido Erreygers, and Wilfried Parys. 2009. 'Our daily bread': Maurice Potron, from Catholicism to mathematical economics. The European Journal of the History of Economic Thought, 16 (1): 123-154.

Blaug, Mark. 2001. No history of ideas, please, we're economists. Journal of Economic Perspectives, 15 (1): 145-164.

Colletti, Lucio. 1969. Il Marxismo e Hegel. Bari: Laterza.

Colletti, Lucio. 1975. Introduction. In Karl Marx's early writings. Harmondsworth: Penguin, 7-56.

Faccarello, Gilbert. 1982. Sraffa versus Ricardo. the historical irrelevance of the corn-profit Model. Economy and Society, 11 (2): 122-137. Republished in The value dimension: Marx versus Ricardo and Sraffa, 1986, ed. Ben Fine. London: Routledge and Kegan Paul, 188-208.

Faccarello, Gilbert. 1983a. Travail, valeur et prix: une critique de la théorie de la valeur. Paris: Anthropos. 
Faccarello, Gilbert. 1983b. La loi de la valeur et le problème de la coordination des activités économiques [On Isaak Illych Rubin]. L'Homme et la Société, 67 (67-68): 153-177.

Faccarello, Gilbert. 1986. Aux origines de l'économie politique libérale: Pierre de Boisguilbert. Paris: Anthropos. Revised edition: The Foundations of Laissez-faire: the Economics of Pierre de Boisguilbert. London: Routlege, 1999.

Faccarello, Gilbert. 1989. L'évolution de la pensée économique pendant la Révolution: Alexandre Vandermonde ou la croisée des chemins. In Politische Ökonomie und Französische Revolution. Trier: Schriften aus dem Karl-Marx-Haus, 75-121.

Faccarello, Gilbert. 1992. Turgot et l'économie politique sensualiste. In Nouvelle histoire de la pensée économique, vol. 1: Des scolastiques aux classiques, eds. Alain Béraud, and Gilbert Faccarello. Paris: La Découverte, 254-288.

Faccarello, Gilbert. 1997. Some reflexions on Marx's theory of value. In Marxian economics: a centenary appraisal, volume I, ed. Riccardo Bellofiore. London: Macmillan, 29-47.

Faccarello, Gilbert. 1997. Galiani, Necker, and Turgot: a debate on economic reforms and policies in eighteenth century France. In Studies in the history of French political economy, ed. Gilbert Faccarello. London: Routledge, 120-195.

Faccarello, Gilbert. 2000. Karl Marx et la critique de l'économie politique: le 'purgatoire du temps présent'. In Nouvelle histoire de la pensée économique, vol. 2: Des premiers mouvements socialistes aux néoclassiques, eds. Alain Béraud, and Gilbert Faccarello. Paris: La Découverte, 62-170.

Faccarello, Gilbert. 2006. An 'exception culturelle'? French Sensationist political economy and the shaping of public economics. The European Journal of the History of Economic Thought, 13 (1): 1-38.

Faccarello, Gilbert. 2009. The enigmatic Mr. Graslin: a Rousseauist bedrock for classical economics? The European Journal of the History of Economic Thought, 16 (1): 1-40.

Faccarello, Gilbert. 2010. Bold ideas: French liberal economists and public economics in 19th century France. The European Journal of the History of Economic Thought, 17 (4): 719-758.

Faccarello, Gilbert. 2010. 'She tells him to be gone'. Population, poverty, and welfare in France during the first 19th century: the heyday of a controversy. Tokyo, Waseda University: Seminar on 'Population, poverty, and welfare in the history of economic thought'.

Faccarello, Gilbert. 2011. A dance teacher for paralytic people? Pauperism and the two births of Christian political economy in 19th century France. Tokyo, Waseda University: Seminar on 'Population, poverty, and welfare in the history of economic thought'.

Faccarello, Gilbert. 2014. From the foundation of liberal political economy to its critique: theology and economics in France in the 18th and 19th centuries. In The Oxford Handbook of Christianity and Economics, ed. Paul Oslington. Oxford: Oxford University Press, 73-93.

Faccarello, Gilbert. 2015. Autopsy of a text: being an enquiry concerning Mr. Ricardo's principles of international trade. The European Journal of the History of Economic Thought. Forthcoming. 
Faccarello, Gilbert, and Philippe Steiner. 2002. The diffusion of the work of Adam Smith in the French language: an outline history. In A critical bibliography of Adam Smith, ed. Keith Tribe. London: Pickering and Chatto, 61-119.

Faccarello, Gilbert, and Philippe Steiner. 2008a. Interests, sensationism, and the science of the legislator: French 'philosophie économique', 1695-1830. The European Journal of the History of Economic Thought, 15 (1): 1-23.

Faccarello, Gilbert, and Philippe Steiner. 2008b. Political economy and religion in early 19th century France. History of Political Economy, 40 (Annual Supplement): 26-61.

Faccarello, Gilbert, and Philippe Steiner. 2012. 'Philosophie économique' and money in France, 1750-1776: the stakes of a transformation. The European Journal of the History of Economic Thought, 19 (3): 325-353.

Keynes, John Maynard. 1924. Alfred Marshall. In The collected writings of John Maynard Keynes, volume X, 1972. London: Macmillan and Cambridge University Press, 161-231.

Kurz, Heinz D. 2006. Wither the history of economic thought? Going nowhere rather slowly. The European Journal of the History of Economic Thought, 13 (4): 463-488.

Mill, John Stuart. 1865. Auguste Comte and Positivism. In Essays on ethics, religion, and society, 1969. Toronto: The University of Toronto Press, and London: Routledge and Kegan Paul, 261-368.

Samuelson, Paul Anthony. 1962. Economists and the history of ideas. The American Economic Review, 51 (1): 1-18.

Steiner, Philippe. 2005. L'École durkheimienne et l'économie. Geneva: Droz. Revised edition: Durkheim and the birth of economic sociology. Princeton: Princeton University Press, 2010.

Steiner, Philippe. 2011. The creator, human conduct, and the maximisation of utility in Gossen's economic theory. The European Journal of the History of Economic Thought, 18 (3): 353-379.

Gilbert Faccarello’s Webpage: http://ggjjff.free.fr/ 